\title{
SYSTEMATIC APPROACH FOR UNGAGED BASINS' DISCHARGE DETERMINATION IN WESTERN PELOPONNESE, GREECE
}

\section{E.I. DANIIL* \\ S.N. MICHAS \\ K. NIKOLAOU \\ L.S. LAZARIDIS}

Received: 05/12/11

Accepted: 25/07/12

\author{
HYDROEXIGIANTIKI \\ 3 Evias str., 15125 Marousi, Greece
}

\begin{abstract}
Determining peak flows for ungaged areas is difficult and involves high uncertainty. Advanced computer capabilities provided by geographical information systems and hydrologic modeling software are used for detailed determination of the parameters involved, both for simple methods as the rational method and more detailed ones as the application of synthetic hydrographs. For the determination of the runoff coefficients and other runoff parameters, digital elevation models were combined with geologic and land use maps in order to extract morphologic and other distributed parameters with the use of GIS for computation of watershed runoff. The discharges were determined by the rational method, the Fuller's formula and a hydrologic model using synthetic hydrographs according to SCS. A dependable estimate of the design discharge is necessary both for demarcation studies of watercourses and the assessment and management of flood risks according to the guidelines of Directive 2007/60/EC.

In this paper a case study in Western Peloponnese is presented. Area specific fitted equations relating the drainage area to the peak flows were developed, that can be used in adjacent regions. The results of the hydrologic studies performed for many geographical units of the new Patra Pyrgos - Tsakona highway, presently under construction, are analyzed and presented. Results of the rational method and modeling with the HEC-HMS system using SCS hydrographs were compared. Transverse drainage works, where the motorway crosses watercourses, were designed with the 50$\mathrm{yr}$ design discharges determined by the hydrologic model with the use of synthetic hydrographs, lag time and CN, depending on land use, geology and soil cover, determined according to SCS. In the case of bridges with piers the corresponding 100-yr values were used. Differences between the rational method and the hydrologic model are not significant in most cases. Pronounced differences were noticed only in the combined presence of high water transmissivity soils and forest cover.
\end{abstract}

Regional equations were developed for use. In the basins used there are no areas with major urban development or basins with control structures. The equations refer to the 50-yr design flood and can be used in any further computation that may be required in the vicinity without further hydrologic analysis. Comparison with other studies shows good agreement and with similar equations from other projects resemblance.

KEYWORDS: hydrologic modeling, ungaged basins, design discharge, regional equations, Peloponnese.

\section{INTRODUCTION}

Determining peak flows for ungaged areas is difficult and involves high uncertainty. A dependable estimate of the design discharge is necessary for sizing of stormwater projects, demarcation studies of watercourses, and the assessment and management of flood risks according to EC guidelines. Directive 2007/60/EC calls for use of appropriate best practice and best available technologies, not entailing excessive costs in the field of flood risk management. Several regional analysis and empirical techniques have been developed to address these situations. Extrapolation of data from 
nearby watersheds with comparable hydrologic and physiographic features is referred to as regional analysis and includes regional regression equations and index-flood methods (U.S. DoT, 2002). Watershed area plays an important role for each of these ungaged watershed peak flow determination methods. Advanced computer capabilities provided by geographical information systems and hydrologic modeling software can be used for detailed determination of the parameters involved, thus improving the accuracy of the prediction. For the determination of the runoff coefficients and other runoff parameters, digital elevation models are combined with geologic and land use maps in order to extract morphologic and other distributed parameters with the use of GIS for computation of watershed runoff. This requires extensive preprocessing of the data before entering them in the hydrologic modeling software. Currently, shared data models, designed using an object - oriented strategy are being developed that will facilitate use of data from the different modules (Kumar et al., 2010). Still, scale issues between the various levels of input information should be resolved.

In Greece according to national guidelines relating to stormwater projects the methods to be used include: the rational method, Fuller's formula and hydrograph development in cases of large basins that should be divided into subbasins. Drainage area is the most important parameter in determining runoff peaks, however the relation is not linear and geologic and morphologic parameters are also important. Complex hydrologic systems should be analyzed using hydrographs and not simply the rational method. Thus, the time and spatial variability of watershed response can be better assessed and the effect of training and retaining works evaluated. Comparison with the rational method, the Fuller equation, and hydrologic modeling with the HEC-HMS system using SCS hydrographs has been presented for case studies in Greece (Daniil and Michas, 2009).

\section{METHODOLOGY FOR DISCHARGE DETERMINATION}

Hydrologic modeling using synthetic hydrographs according to SCS is used including a number of subbasins, depending on the size and morphology of each basin. Use of GIS aids considerably in the estimation of related parameters for time of concentration, time lag, abstractions, runoff coefficient depending on three parameters: surface slope, soil, and land use for all subbasins considered. Especially in the case of complex systems involving large basins with many subbasins hydrologic modeling is definitely superior, providing more insight in the hydrological processes and watershed response as compared to the single peak value obtained from the rational method.

Area specific fitted equations relating the drainage area to the peak flows can be developed and used in adjacent regions.Power law equations relating discharge and drainage area give an exponent in the order of 0.75 for various parts of Greece, whereas the constant of proportionality is influenced by the geographic location, soil characteristics, elevation and orographic effects. Comparisons with the rational method, the Fuller equation, and hydrologic modeling with the HECHMS system using SCS hydrographs has been presented for case studies in Greece (Daniil and Michas, 2009, Daniil et al., 2008).

\section{Time of concentration - Lag time}

In the rational method a key parameter resulting in high uncertainty is the estimation of the time of concentration for which the rainfall intensity is computed. A well known formula is Kirpich's formula. In the literature an adjustment factor is mentioned that amounts to 2 in the case of general overland flow and natural grass channels and may be as low as 0.2 for the case of flow in concrete channels (Chin, 2000, Chow et al., 1988), but it is not usually used in the computations. Kirpich's formula gives considerably lower values than Giandotti's formula, also mentioned in PD 696/74 providing the guidelines for the design of stormwater projects in Greece. Many times Kirpich's formula is used for small watersheds, while Giandotti's for larger (e.g. A>3km²). In Design of Small Dams (U.S.B.R., 1977 ) for watersheds west of the $105^{\circ}$ meridian as well as for timbered watersheds in mountainous regions east of the $105^{\circ}$ meridian the time of concentration computed with the CCP (California Culvert Practice) formula, which essentially the same with Kirpich's formula, if the mean slope is taken as $\mathrm{Sm}=\mathrm{H} / \mathrm{L}$, is adjusted to reflect the retardance effect according Table 1 for values of $\mathrm{CN}<80$. 
Table 1. Correction factor for time of concentration for timbered watersheds

\begin{tabular}{ccccc}
\hline CN & 80 & 70 & 60 & 50 \\
\hline correction factor tc'/tc & 1.0 & 1.4 & 1.8 & 2.2 \\
\hline
\end{tabular}

The lag time of the unit hydrograph according to SCS is taken equal to 0,6 of the time of concentration:

$\mathrm{t}_{\text {lag }}$ (hours) $=\frac{\ell^{0.8}(\mathrm{~S}+1)^{0.7}}{1900 \mathrm{y}^{0,5}}$ or $\mathrm{t}_{\text {lag }}(\min )=60 \frac{\ell^{0.8}(\mathrm{~S}+1)^{0.7}}{1900 \mathrm{y}^{0,5}}$

where: $\ell$ the watercourse length up to the divide (ft), y the average watershed slope (\%), $S=1000 / C N-10, C N$ the "curve number", parameter accounting for abstractions, depending on geology and land use conditions. In the above formula often instead of average watershed slope mean watercourse slope is used. In watersheds with steep hillside slopes the average watershed slope can be double the watercourse slope. In such a case if the watercourse slope is used, lag time is longer by $41 \%$ as compared to the time computed using the watershed slope (Daniil and Michas, 2006).

\section{SCS abstractions}

Total runoff is computed as: $\quad Q=\frac{(P-0.2 S)^{2}}{(P+0.8 S)}$

where: $S$ is the potential maximum retention and the initial abstraction before ponding is taken as $\mathrm{la}=0.2 \mathrm{~S}, \mathrm{Q}$ is the runoff in $\mathrm{mm}$ and $\mathrm{P}$ the rainfall height in $\mathrm{mm}, \mathrm{S}$ in $\mathrm{mm}$ is given by the formula: $S=(1000 / C N-10) \times 25.4, C N$, the curve number, ranges form $0-100$ and depends on soil conditions.

Curve numbers have been tabulated by the Soil Conservation Service on the basis of soil type and land use. $\mathrm{CN}$ values depend also on antecedent soil moisture conditions, that can be dry conditions (AMC I), normal (AMC II) or wet (AMC III). Tabulated CN values for normal conditions are usually used. Four soil groups are defined by the Soil Conservation Service (Bedient and Huber, 1988, U.S. DoT, 2002):

Group A - soils with high rate of water transmission - low runoff potential.

Group B - soils having moderate rate of water transmission.

Group C - soils having a slow rate of water transmission.

Group D - Soils having very slow rate of water transmission - high runoff potential.

For the selection of appropriate $\mathrm{CN}$ values combined data from the geologic and soil maps of the area as well as land use data were taken into account using GIS.

Ponce and Hawkins (1996) conclude: Perceived advantages of the method are (1) its simplicity; (2) its predictability; (3) its stability; (4) its reliance on only one parameter; and (5) its responsiveness to major runoff-producing watershed properties (soil type, land/use treatment, surface condition, and antecedent condition). Perceived disadvantages are (1) its marked sensitivity to curve number; (2) the absence of clear guidance on how to vary antecedent condition; (3) the method's varying accuracy for different biomes; (4) the absence of explicit provision for spatial sale effects; and (5) the fixing of the initial abstraction at 0.2 , preempting a regionalization based on geologic and climatic setting. A recent extensive review of the CN method is given by ASCE (2009).

As detailed information about the condition of agricultural areas and forest is not always easily available and design is usually required to project land uses in the order of 30 years in the future, appropriate categories were grouped and mean values assigned as shown in Table 2. Available computer programs allow for the use of other methods of abstractions or the variation of percentage of the initial abstraction. 
Table 2. Basic CN values used for hydrologic modeling

\begin{tabular}{|c|c|c|c|c|c|}
\hline \multirow{2}{*}{$\begin{array}{c}\text { land } \\
\text { use code }\end{array}$} & \multicolumn{4}{|c|}{ Geologic category } & \multirow[t]{2}{*}{ Land use description } \\
\hline & A & B & C & D & \\
\hline $\begin{array}{l}112 \\
121 \\
\end{array}$ & 59 & 73 & 82 & 86 & $\begin{array}{l}\text { Discontinuous urban fabric } \\
\text { Industrial or commercial units }\end{array}$ \\
\hline $\begin{array}{l}211 \\
212 \\
221 \\
222 \\
223 \\
242 \\
243\end{array}$ & 67 & 76 & 83 & 86 & $\begin{array}{l}\text { Non-irrigated arable land } \\
\text { Permanently irrigated land } \\
\text { Vineyards } \\
\text { Fruit trees and berry plantations } \\
\text { Olive groves } \\
\text { Complex cultivation patterns } \\
\text { Agricultural land with areas of natural vegetation }\end{array}$ \\
\hline $\begin{array}{l}311 \\
312 \\
313\end{array}$ & 33 & 60 & 72 & 78 & $\begin{array}{l}\text { Broad-leaved forest } \\
\text { Coniferous forest } \\
\text { Mixed forest }\end{array}$ \\
\hline $\begin{array}{l}321 \\
323 \\
324 \\
331 \\
332 \\
333\end{array}$ & 53 & 70 & 80 & 84 & $\begin{array}{l}\text { Natural grasslands } \\
\text { Sclerophyllous vegetation } \\
\text { Transitional woodland - shrub } \\
\text { Beaches, dunes, sands } \\
\text { Bare rocks } \\
\text { Sparsely vegetated areas }\end{array}$ \\
\hline $\begin{array}{l}411 \\
512\end{array}$ & 90 & 90 & 90 & 90 & $\begin{array}{l}\text { Inland marshes } \\
\text { Water bodies }\end{array}$ \\
\hline
\end{tabular}

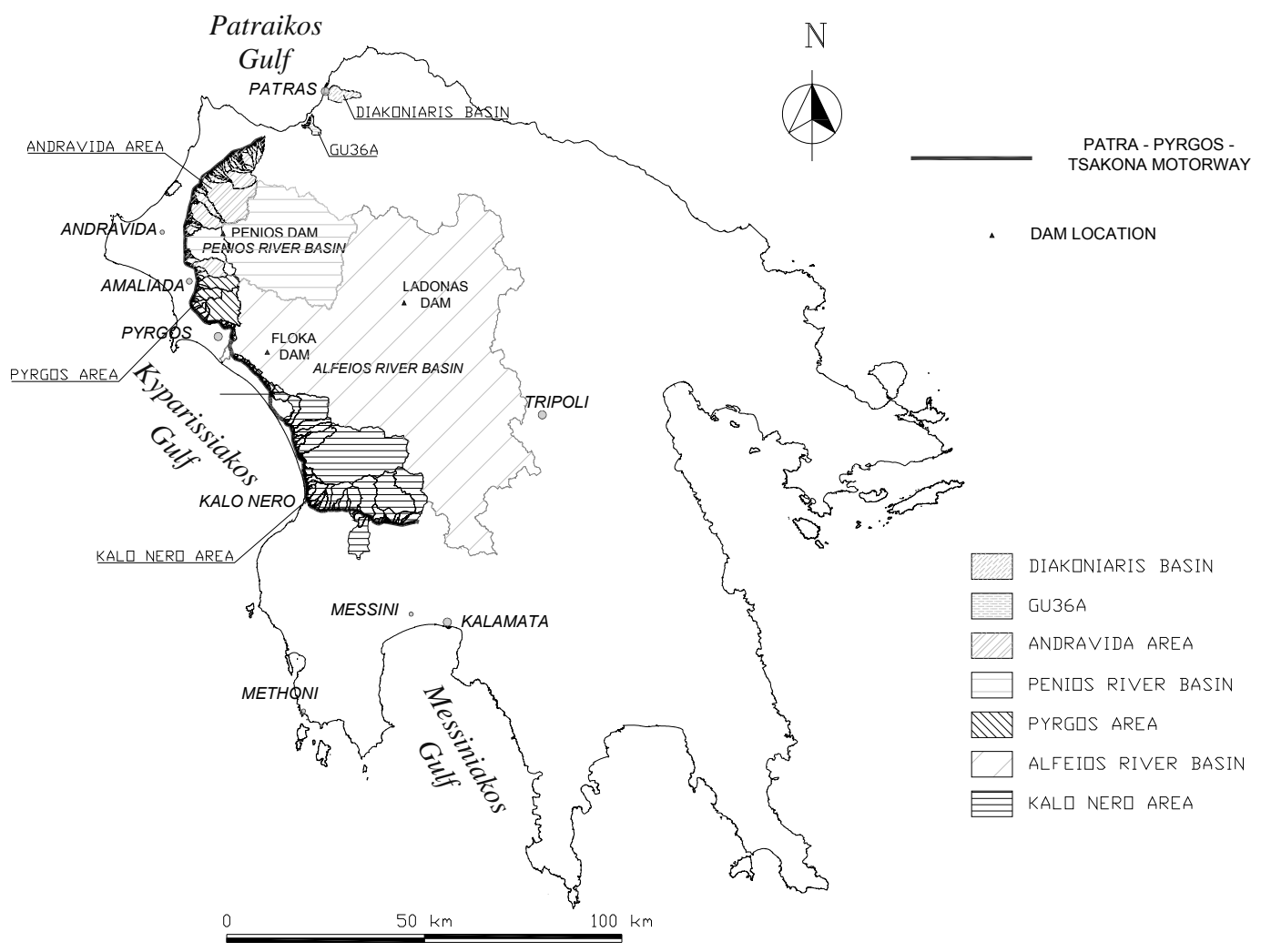

Figure 1. Schematic Map of Peloponnese and regions studied 


\section{CASE STUDY}

A case study in Western Peloponnese is presented, based on results of hydrologic studies performed for many geographical units of the new Patra - Pyrgos - Tsakona highway, presently under construction. The new motorway from Patra to Pyrgos generally passes through the same zone as the existing road, through the extended flat terrain that covers a large part of NW Peloponnese. The western boundaries of this terrain are the coastline and the eastern the mountains Panachaiko, Erymanthos, Skolli, Foloi, Minthi and Tetrazio. The continuity of these mountains is interrupted only by the Alfios River valley, which extends through mountains Foloi \& Minthi (at a long route towards East). The new Pyrgos - Tsakona Motorway follows, in general terms, the same route as the existing road. It travels south from Pyrgos to Kalo Nero and then turns east through the valley bounded by Mt. Tetrazio to the north and the Kyparissia mountains to the south, until it intersects the Tripolis - Kalamata Motorway at Tsakona, where the Olympian Highway ends (Figure 1).

\section{IDF curves}

The final intensity - duration - frequency (idf) curves approved by the Independent Engineer for use in the hydraulic studies are summarized in Table 3.

Table 3. Approved forms of idf curves for Olympia Odos Motorway

\begin{tabular}{|c|c|c|c|c|}
\hline & Area & $\begin{array}{c}\text { idf curve } \\
\mathrm{i}\left(\mathrm{mm} \mathrm{hr} \mathrm{m}^{-1}\right)\end{array}$ & $\begin{array}{c}\mathrm{H}(\mathrm{mm}) \\
\mathrm{T}=50, \mathrm{~d}=12 \mathrm{hrs}\end{array}$ & origin of idf curve \\
\hline 1 & $\begin{array}{c}\text { section from } \\
\text { Korinthos to Kato } \\
\text { Loutro }\end{array}$ & $i=\frac{50.44\left(T^{0.16}-0.636\right)}{(0.0679+d)^{0.732}}, \mathrm{~d}(\mathrm{hr})$ & 120.6 & $\begin{array}{c}\text { Xirias stream } \\
\text { (Koutsoyiannis) }\end{array}$ \\
\hline 2 & $\begin{array}{c}\text { Section from Kato } \\
\text { Loutro and up to } \\
15 \mathrm{~km} \text { south of } \\
\text { Mintilogli }\end{array}$ & $i=\frac{20.31 T^{0.28}}{d^{0.59}}, \mathrm{~d}(\mathrm{~min})$ & 149.6 & $\begin{array}{c}\text { Patra (Dallas } \\
\text { curve) used for } \\
\text { the design of } \\
\text { many works }\end{array}$ \\
\hline 3 & $\begin{array}{c}\text { Section15 km south } \\
\text { of Mintilogli and up to } \\
\text { 15km north of Pyrgos }\end{array}$ & $i=\frac{1009.7 T^{0.153}-389.45}{(7.5+d)^{0.77}}, \mathrm{~d}(\mathrm{~min})$ & 108.7 & $\begin{array}{c}\text { Andravida idf } \\
\text { (Kalleris study) }\end{array}$ \\
\hline 4 & $\begin{array}{c}\text { Section 15km north of } \\
\text { Pyrgos to 15km south } \\
\text { of Pyrgos }\end{array}$ & $i=\frac{495.44 T^{0.142}-70.76}{(2.5+d)^{0.69}}, \mathrm{~d}(\mathrm{~min})$ & 101.3 & $\begin{array}{c}\text { Pyrgos idf } \\
\text { (Kalleris study) }\end{array}$ \\
\hline 5 & $\begin{array}{c}\text { From 15 km south of } \\
\text { Pyrgos to Tsakona }\end{array}$ & $\begin{array}{c}\text { For d }>6 \mathrm{hrs}, \text { Pyrgos idf }(4) \\
\text { for } \mathrm{d}<6 \mathrm{hrs}, \text { Methoni idf }\end{array}$ & $\begin{array}{c}101.3 \\
(95.9)\end{array}$ & $\begin{array}{c}\text { Pyrgos idf } \\
\text { (Kaleris study) } \\
\text { and Methoni idf } \\
\text { (Kaleris study) }\end{array}$ \\
\hline
\end{tabular}

where: $\mathrm{T}=$ recurrence interval (years), $\mathrm{d}=$ rainfall duration

Due to the fact that the prevailing weather systems reach the western coast of Peloponnese from the west and based on the relief of the area, it is apparent that the precipitation is of the orographic type. A center-loaded $12 \mathrm{hr}$ storm based on the appropriate idf curve was used in each case.

\section{Soil cover and land use characteristics}

The number of basins and the distribution of the area of each section studied in soil groups (water transmissivity), land use and surface slope categories is given in Table 4, giving a concise representation of the main characteristics, is a useful aid in further grouping for the analysis of the results. In figures 2, 3 the distribution of land use and water transmissivity in the study area are shown.

\section{RESULTS}

Hydrologic modeling in the HEC-HMS environment was used for the determination of the design discharges. SCS hydrographs, with SCS lag time and abstractions were used. Fuller's formula overestimates discharge considerably, especially for drainage areas up to $1 \mathrm{~km}^{2}$. Results of the rational method and modeling with the HEC-HMS system using SCS hydrographs were compared 
and differences were not significant in most cases. Pronounced differences were noticed in the presence of Group A soils and forests. This can be attributed to a large extent to the use of Kirpich's formula without adjustment factor. In Figure 4 variation of time of concentration for the 37 watersheds in GU48A computed according to Kirpich (tKirp), Kirpich adjusted in relation to CN (tKirp_m), Giandotti (tGiand) and SCS is shown.

Table 4. Distribution of drainage area in water transmissivity, land use and surface slope categories (\%) in the motorway sections studied

\begin{tabular}{|c|c|c|c|c|c|c|c|c|c|c|c|c|c|}
\hline & & & & \multicolumn{4}{|c|}{ Water transmissivity } & \multicolumn{3}{|c|}{ Land Use } & \multicolumn{3}{|c|}{ Surface slope } \\
\hline $\begin{array}{l}\text { Section-G.U./ } \\
\text { Chainage }\end{array}$ & $\begin{array}{c}\text { Drain. } \\
\text { Area } \\
\left(\mathrm{km}^{2}\right)\end{array}$ & $\begin{array}{l}\text { \# of } \\
\text { bas. }\end{array}$ & IDF & $\begin{array}{c}\text { A } \\
\text { High }\end{array}$ & $\begin{array}{c}\text { B } \\
\text { Mode- } \\
\text { rate }\end{array}$ & $\begin{array}{c}\text { C } \\
\text { Slow }\end{array}$ & $\begin{array}{c}\text { D } \\
\text { Very } \\
\text { slow }\end{array}$ & $\begin{array}{l}\text { Agric. } \\
\text { areas }\end{array}$ & $\begin{array}{c}\text { Forests, } \\
\text { shrubs }\end{array}$ & $\begin{array}{l}\text { Urban } \\
\text { areas }\end{array}$ & $0 \sim 5 \%$ & $5 \sim 20 \%$ & $>20 \%$ \\
\hline $\begin{array}{l}\text { PAPY 36A } \\
0+287-4+110\end{array}$ & 9.7 & 16 & 2 & & 1.7 & 78.2 & 20.1 & 74.3 & 25.6 & 0.1 & 12.4 & 51.1 & 36.6 \\
\hline \multicolumn{4}{|c|}{ 36B - Peiros basin area } & & & & & & & & & & \\
\hline $\begin{array}{l}\text { PAPY 36C } \\
14+700-18+500\end{array}$ & 11.3 & 10 & 3 & & 84.0 & 0.6 & 15.4 & 92.4 & 7.6 & & 84.2 & 12.3 & 3.5 \\
\hline $\begin{array}{l}\text { PAPY } 37 \\
18+500-33+500\end{array}$ & 87.0 & 27 & 3 & & 27.8 & 30.6 & 41.6 & 73.1 & 26.6 & 0.3 & 54.5 & 32.3 & 13.2 \\
\hline $\begin{array}{l}\text { PAPY } 38 \\
33+500-46+500\end{array}$ & 154.8 & 32 & 3 & & 15.3 & 68.7 & 16.0 & 79.9 & 20.1 & & 51.6 & 36.9 & 11.5 \\
\hline $\begin{array}{l}\text { PAPY 39* } \\
46+500-58+000\end{array}$ & 17.9 & 17 & 3 & & 9.7 & 90.3 & & 91.9 & 8.0 & & 81.9 & 15.7 & 2.4 \\
\hline $\begin{array}{l}\text { PAPY } 40 \\
58+000-74+500\end{array}$ & 100.8 & $11 / 19$ & $3 / 4$ & & 25.1 & 74.9 & & 82.4 & 17.6 & & 24.6 & 42.4 & 32.9 \\
\hline $\begin{array}{l}\text { PAPY } 41 \\
74+500-85+500\end{array}$ & 65.3 & 22 & 4 & & 40.6 & 59.4 & & 93.7 & 5.7 & 0.6 & 29.4 & 39.2 & 31.4 \\
\hline \multicolumn{4}{|c|}{42 - Alfeios basin area } & & & & & & & & & & \\
\hline $\begin{array}{l}\text { PYTSA } 43 \\
2+420-10+000\end{array}$ & 8.5 & 19 & 4 & & 24.3 & 75.7 & & 94.0 & & 6.0 & 49.7 & 31.1 & 19.2 \\
\hline $\begin{array}{l}\text { PYTSA 44 } \\
10+000-16+611\end{array}$ & 17.2 & 17 & 5 & 22.7 & 13.4 & 64.0 & & 69.1 & 30.9 & & 24.8 & 36.8 & 38.4 \\
\hline \multicolumn{4}{|c|}{45 - Lake Kaiafa area } & & & & & & & & & & \\
\hline $\begin{array}{l}\text { PYTSA } 46 \\
24+000-27+000\end{array}$ & 66.1 & 6 & 5 & 35.8 & 22.5 & 28.5 & 13.3 & 65.6 & 33.2 & 1.2 & 11.6 & 38.4 & 50.0 \\
\hline $\begin{array}{l}\text { PYTSA } 47 \\
27+000-33+500\end{array}$ & 63.9 & 10 & 5 & 42.2 & 53.5 & 0.1 & 4.2 & 63.2 & 36.8 & & 7.0 & 36.6 & 56.4 \\
\hline $\begin{array}{l}\text { PYTSA 48A } \\
33+500-45+000\end{array}$ & 294.7 & 37 & 5 & 54.5 & 32.3 & & 13.1 & 34.9 & 64.9 & 0.1 & 5.5 & 24.3 & 70.1 \\
\hline $\begin{array}{l}\text { PYTSA 48B } \\
45+000-49+043\end{array}$ & 22.1 & 13 & 5 & 19.4 & 69.6 & 8.3 & 2.7 & 48.1 & 51.9 & & 18.5 & 50.2 & 31.2 \\
\hline $\begin{array}{l}\text { PYTSA } 49 \\
49+043-61+483\end{array}$ & 65.0 & 18 & 5 & 37.9 & 52.6 & & 9.5 & 74.1 & 25.0 & 0.9 & 27.4 & 41.1 & 31.6 \\
\hline $\begin{array}{l}\text { PYTSA } 50-51 \\
61+483-76+160\end{array}$ & 229.7 & 48 & 5 & 38.3 & 53.1 & & 8.7 & 48.6 & 50.6 & 0.8 & 26.4 & 25.0 & 48.6 \\
\hline
\end{tabular}

${ }^{*}$ Pinios basin $\left(A=784.6 \mathrm{~km}^{2}\right)$ not included

PAPY = Patra - Pyrgos, PYTSA = Pyrgos - Tsakona, G.U. = Geographical Unit of Olympia Motorway 


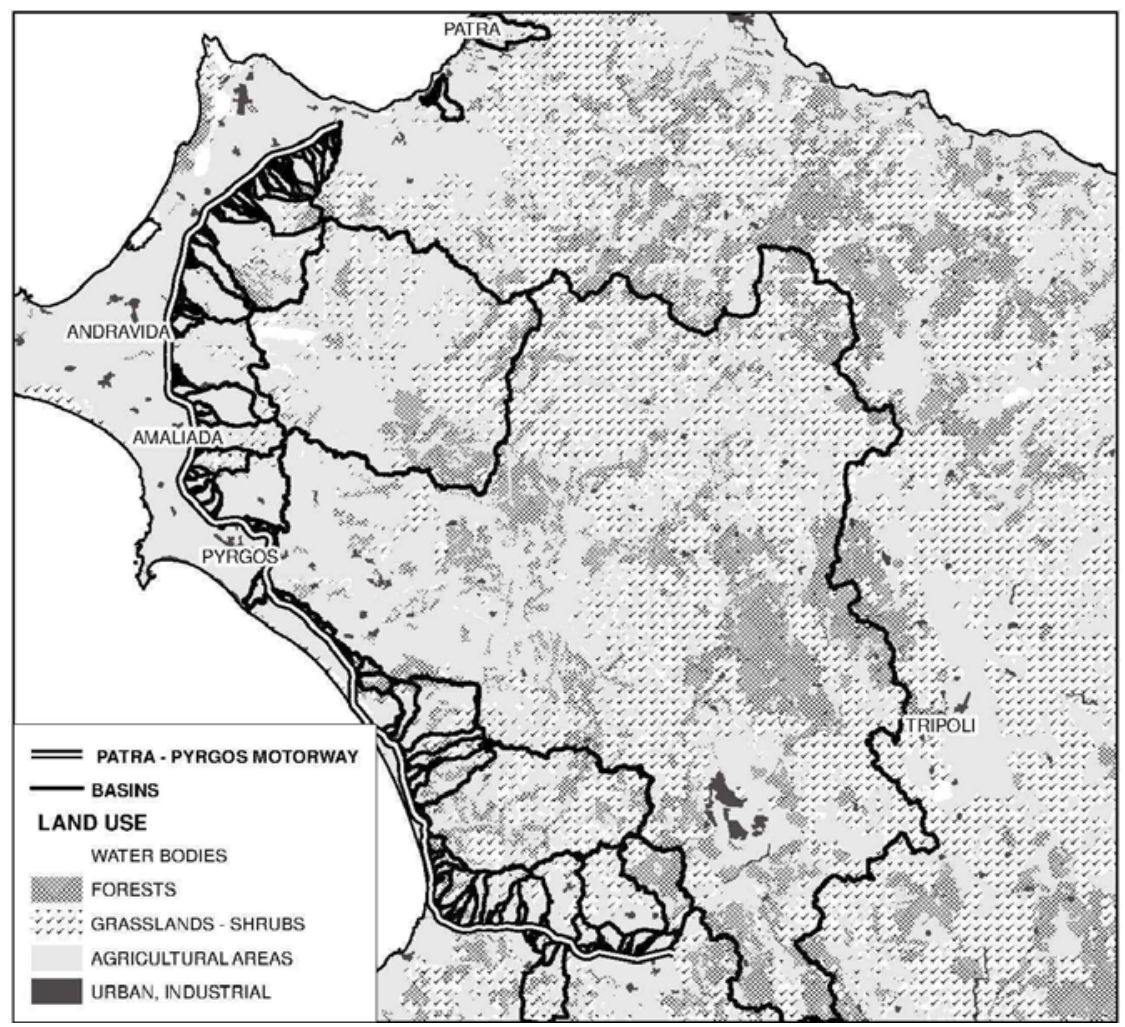

Figure 2. Land use distribution in the case study area

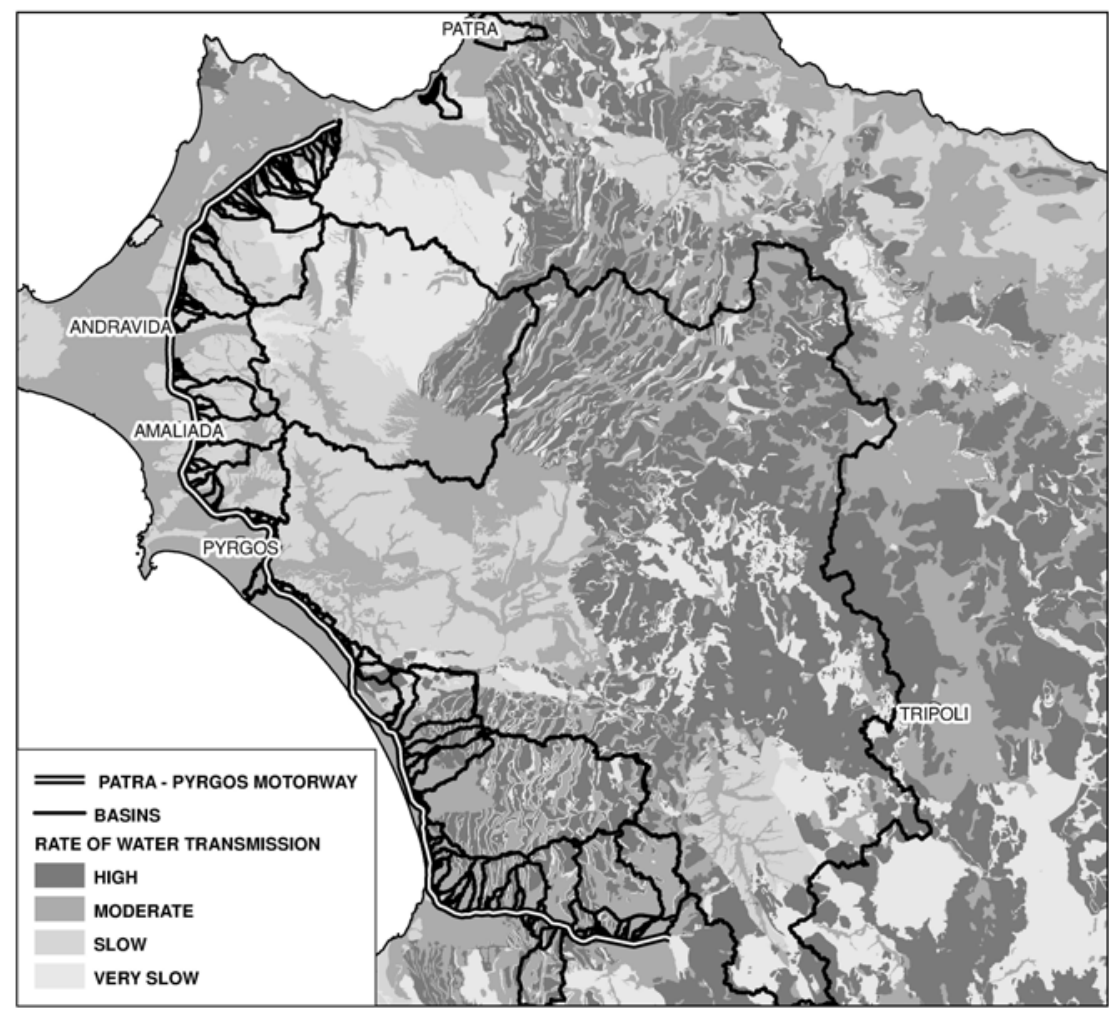

Figure 3. Water transmission categories' distribution in the case study area 


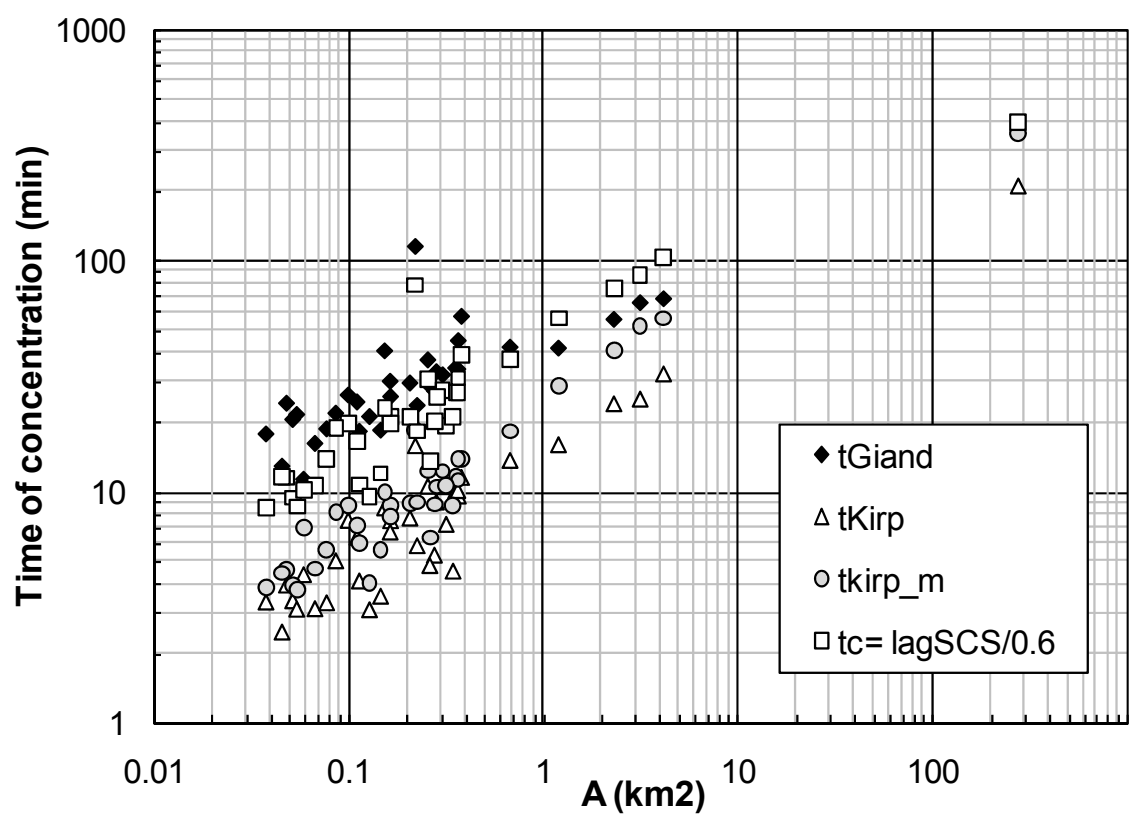

Figure 4. Comparison of time of concentration estimates with different methods for watersheds in section GU48A

\section{Regional equations}

Regional equations were developed for use based on the results of the hydrological modeling. In the basins used there are no areas with major urban development or basins with control structures (e.g. irrigation dams). The equations refer to the $50-y r$ design flood and can be used in any further computation that may be required without further hydrologic analysis. Transverse drainage works, where the motorway crosses watercourses were designed with the 50-yr design discharges determined by the hydrologic model with the use of synthetic hydrographs, lag time and $\mathrm{CN}$, depending on land use, geology and soil cover, determined according to SCS. In the case of bridges with piers the corresponding $100-y r$ values were used. Fuller' s formula applied without modification of the constants, shows dependence only on drainage area and as a result deviates considerably as compared to the results of other methods. In most geographical units, especially for small drainage areas the estimated discharge by Fuller's formula is even higher than the 100-yr discharge computed by the hydrological model. For the development of the regional equations results were grouped based on the applicable idf curve and soil cover and land use. The obtained results for $\mathrm{T}=50 \mathrm{yrs}$ were grouped in four regions and equations of the form of equation 3 were fitted for each area.

Q50 $\left(\mathrm{m}^{3} \mathrm{~s}^{-1}\right)=\mathrm{a} \mathrm{A}\left(\mathrm{km}^{2}\right)^{\mathrm{b}}$

The fitted equations developed are shown in Figure 5 along with the corresponding data.. In table 4 the constants, the correlation coefficient $\left(R^{2}\right)$ and the number of data $(N)$ used for the regional equations developed, are summarized. The exponent does not vary significantly $(0.68-0.85)$, while the constant of proportionality although in the same order of magnitude almost triples within the study area ranging from 6.01 to 17.27 .

\section{Comparisons with other studies}

Equations derived for other projects are also given for comparison in Table 5.

Diakoniaris river is located near Patra city, it has ephemeral flow and flows from south to north with a drainage area of $\mathrm{km}^{2}$ (Figure 1). Applying eq. (3.1) yields $Q 50=228 \mathrm{~m}^{3} \mathrm{~s}^{-1}, 6.5 \%$ higher than the discharge of $214 \mathrm{~m}^{3} \mathrm{~s}^{-1}$ determined in the relevant study (Hydroexigiantiki, 2002). 


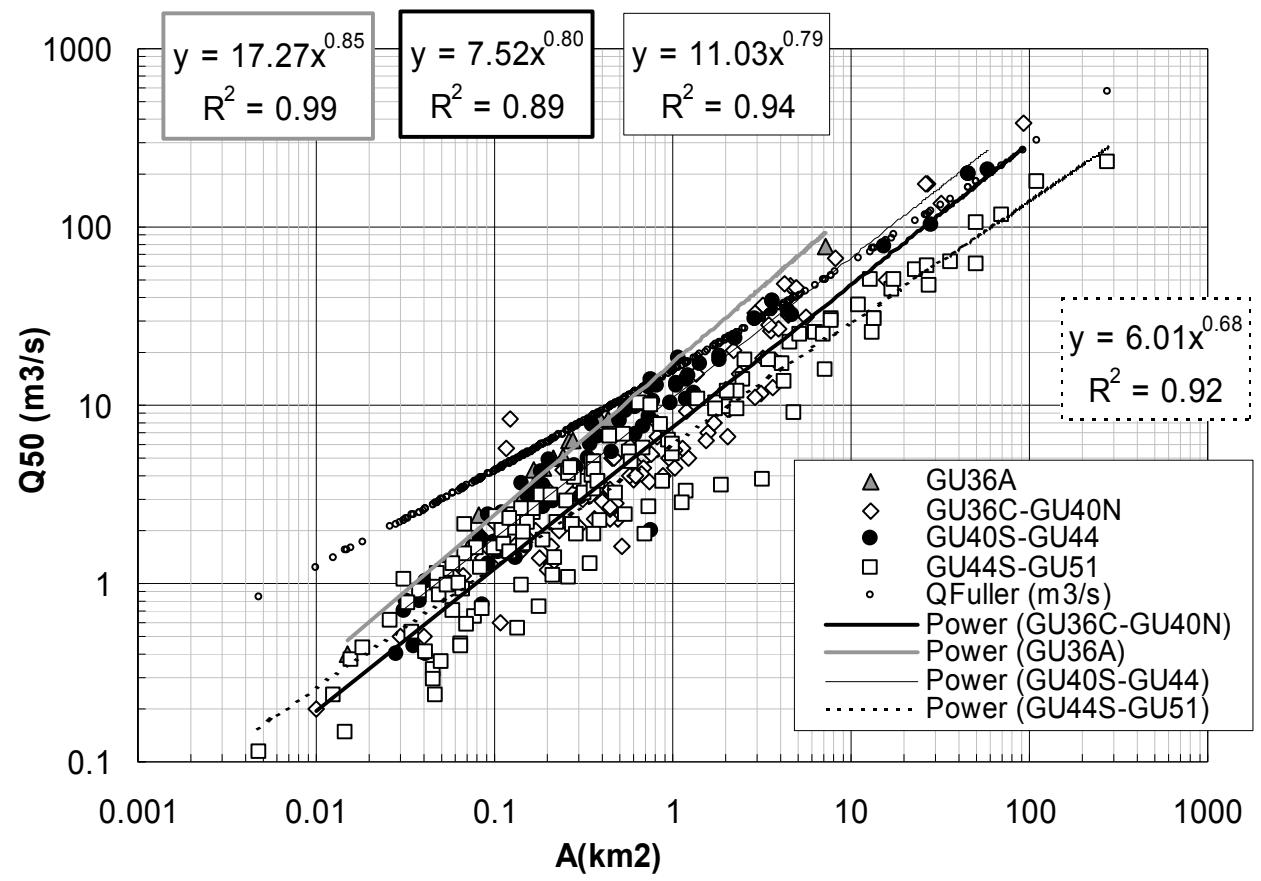

Figure 5. Hydrologic modeling results and fitted regional equations

Table 5. Constants of regional equations

\begin{tabular}{|c|c|c|c|c|c|c|}
\hline eq. & Region & $\mathbf{N}$ & $\mathbf{a}$ & b & $\mathbf{R}^{2}$ & Comments \\
\hline 3.1 & West of Patra & 16 & 17.27 & 0.85 & 0.989 & based on GU36A \\
\hline 3.2 & Andravida & 97 & 7.52 & 0.80 & 0.894 & $\begin{array}{l}15 \mathrm{~km} \text { south of Mintilogli to } 15 \mathrm{~km} \\
\text { north of Pyrgos (based on data from } \\
\text { GU36C-GU40North) }\end{array}$ \\
\hline 3.3 & Pyrgos & 75 & 11.03 & 0.79 & 0.943 & $\begin{array}{l}15 \mathrm{~km} \text { around Pyrgos (based on data } \\
\text { from GU40South-GU44) }\end{array}$ \\
\hline 3.4 & Kalo Nero & 134 & 6.01 & 0.68 & 0.915 & $\begin{array}{l}\text { From } 15 \mathrm{~km} \text { south of Pyrgos to Kalo } \\
\text { Nero and to Tsakona to the east } \\
\text { (based on data from GU44South- } \\
\text { GU51) }\end{array}$ \\
\hline 3.6 * & Stylis area & & 6.96 & 0.75 & 0.977 & PATHE highway \\
\hline 3.7 * & Central Greece -WEST & & 13.49 & 0.78 & 0.985 & Kalabaka-loannina railway project \\
\hline 3.8 * & Central Greece -EAST & & 9.16 & 0.80 & 0.981 & Kalabaka-Ioannina railway project \\
\hline
\end{tabular}

* as given in Daniil et al. (2008)

The variation of the exponent is small in the equations presented in Table 4, but the constant of proportionality shows considerable variation depending on geographic location, soil characteristics, rainfall height, elevation and orographic effects. Inclusion of additional parameters in equation 5 like rainfall height, surface slope and a parameter for abstractions resulting in an expression applicable to the whole region would be desirable. Some attempted correlations though did not give good correlation coefficients and were not pursued further. Furthermore no discharge measurements are available for calibration as most steams are ephemeral. It was thus preferred to have more regional equations with higher correlation coefficients. 


\section{CONCLUSIONS}

Use of geographical information systems for the processing of morphologic and soil cover and land use data obtained from pertinent maps for creating input for hydrologic modeling has proven very useful. With the use of hydrologic modeling software hydrographs and discharge peaks were determined for areas along the west Peloponnese coast. After grouping results four regional equations were obtained and proposed for use in other projects in the area or adjacent areas. The equations relate the peak 50-yr discharge to the drainage area by a power law. The equations do not apply in the case of basins with considerable urban development or major control structures as dams. Comparison with results of other studies in nearby locations shows good agreement, while similar equations have been developed for other parts of Greece.

\section{REFERENCES}

Hawkins R.H., Ward T.J., Woodward D.E., Van Mullem J.A. (eds). (2009), ASCE, Environmental and Water Resources Institute Curve Number Hydrology.

Bedient P.B. and Huber W.C. (1988). Hydrology and Floodplain Analysis, Addison-Wesley Publishing Company.

Chin D.A. (2000), Water Resources Engineering, Prentice Hall.

Chow V.T., Maidment D.R. and Mays L.W. (1988), Applied Hydrology, Mc Graw-Hill.

Daniil E.I. and Michas S.N. (2006), Discussion of "Factors Affecting Estimates of Average Watershed Slope" by A. Jason Hill and Vincent S. Neary, 2005, 10(2), 133-140, J. of Hydrologic Engineering, ASCE, 2006, 11(4), 382-384 (EWRI 2008 Best discussion award).

Daniil E.I. and Michas S.N. (2009) Use of digital elevation models for the determination of stormwater discharges for highway and railway projects, 33rd IAHR Congress, Water Engineering for a sustainable environment, 9-14 Aug. 2009, Vancouver, BC, Canada.

Daniil E.I., Michas S.N. and Aerakis G.S. (2010), Hydrologic and hydraulic computations for watercourse demarcation in Greece, In: Environmental Hydraulics, Christodoulou \& Stamou (eds), 1, pp 349354.

Daniil E.I., Michas S.N. and Lazaridis L.S. (2008), On the determination of design discharges in ungaged basins for highway and railway projects, Conf. Protection and Restoration of the Environment IX, Kefalonia, Greece, 29 June - 3 July 2008.

Hydroexigiantiki (2002), Flood Protection works of Diakoniaris Stream upstream and downstream of the Patra motorway bypass, Preliminary study, MEPPW (In Greek).

Kaleris V. and Demetracopoulos A., (2008). Determination of IDF curves for the area of western Greece from Patras to Pyrgos, University of Patras (In Greek).

Kaleris V. and Demetracopoulos A., (2009). Determination of IDF curves for the area of western Greece from Pyrgos to Tsakona, University of Patras (In Greek).

Kumar M., Bhatt G. and Duffy C.J. (2010), An object-oriented data model for GIS and distributed hydrologic models, Int. J. of Geographical Information Science, 24(7), 1061-1079.

Ponce V.M. and Hawkins R.H. (1996), Runoff Curve Number: Has It Reached maturity?, J. Hydrol. Eng., 1(1), pp. 11-19.

U.S. (2002). Dept. of Transportation, Federal Highway Administration, Hydraulic Design Series No. 2, 2nd Ed., Highway Hydrology, Pub. No. FHWA-NHI-02-001.

U.S. (1977). Department of the Interior, Bureau of Reclamation, Design of Small Dams, 2nd edition, U.S. Government Printing Office, Denver, CO. 